\title{
Profitability Variables and Bank Size Effects on Corporate Zakat: Evidence from Indonesian Islamic Banks
}

\author{
Muhammad Anif Afandi \\ University of Indonesia
}

\begin{abstract}
Islamic banks carry out their operational activities based on Islamic principles. Thus, they are not only required to pay taxes but also zakat of 2.5 percent with several conditions. Theoretically, zakat has an impact on Islamic banks larger expenditures compared to conventional banks which are not obliged to. This research examines and analyzes the extent to which profitability variables which are ROA, ROE, and BOPO, and bank size which is represented by total assets, can affect corporate zakat expenditure by Islamic Commercial Banks (BUS) in Indonesia. To do so, the Panel Vector Error Correction Model (PVECM) is used to analyze the subject matters which the period covers from 2012 to 2017. This work finds that in the short-run, all the independent variables were insignificant. However, in the long-run only ROE and BOPO which were significant. The results of the Impulse Response Function (IRF) analysis showed that the dependent variable responds to the shock of its independent variables with fluctuating and even negative trend. In addition, the results of Variance Decomposition (VDC) analysis showed that the contribution of profitability variables and bank size tended to decrease toward the formation of corporate zakat expenditure by BUS until the end of the research period.
\end{abstract}

Keywords: Corporate Zakat Expenditure, Islamic Banks, Profitability, Bank Size, PVECM

\section{INTRODUCTION}

Zakat is an obligation to pay from wealth ownership of humans who fulfill the requirements as muzaki (obligatory zakat) which is paid to mustahik (zakat recipients), with the aim of wealth purifying. The command of zakat is in the Qur'an which several of that have been ordered in the Q.S. Al-Baqarah:267 and Q.S. At-Taubah:103. According to the National Zakat Board (BAZNAS) (2016), zakat not only has the function to distribute wealth to helping the mustahik's economy but also will transform mustahik into muzaki. This role shows that zakat can overcome gaps and poverty that occur in a country.
Islamic Commercial Banks (BUS) are financial institutions that carry out their operational activities based on Islamic principles. As a consequence, the BUS is obliged to conduct provisions originating from both religious and positive law. Based on Islamic law, BUS should pay zakat maal if the net profit generated in one year exceeds the nisab. Meanwhile, based on positive law, the obligation to pay zakat is regulated in Law No. 23 of 2011, Article 4 Section (3), which explains the obligation to pay zakat maal is carried out by individuals and business entities.

According to Financial Services Authority (FSA) Republic of Indonesia 
(2018), as of 2017, there is 13 BUS operating in Indonesia with total assets of Rp 435.02 trillion, which increased by Rp 69.36 trillion from 2016. Then, FSA (2018) explained that in 2017 the growth of Islamic banking still showed a relatively good number even though it was slowing compared to 2016, which is seen from the growth of total assets, distributed financing (PYD), and thirdparty funds (DPK), which has reached 18.97 percent, 15.24 percent, and 19.83 percent, year-on-year, respectively. In addition, other factors that affect the growth of Islamic banking in 2017 were supported by the increase in capital, adequate liquidity, improved quality of financing, level of efficiency, and profitability of Islamic banks.

According to Firdaus et al. (2012), the potential of zakat in Indonesia in 2011 was Rp 217 Trillion or 3.4 percent from Indonesia's total GDP. This amount included the potential of zakat from various sectors including from BUS. However, in its recent realization, as of BAZNAS National Statistics (2018) reported; in 2017, the collected zakat was around Rp 6.2 trillion. Further, it is informed that recently collected zakat fund by BAZNAS was mostly from individual zakat.

BAZNAS (2016) stated that the awareness of zakat payment for a company or business entity is not as impressive as those of the individual zakat. BAZNAS (2016) highlighted further the low knowledge of a business entity on zakat payment due to the growth of corporate muzaki tended to be slow during the period 2012 - 2016. Whereas, Presidential regulation No. 3 of 2014 has clearly instructed that a corporate or company must pay and collect zakat, both employee zakat, and corporate zakat through BAZNAS.
As above described, the disharmony between the potential and realization of corporate zakat by BUS, demands further research to analyze whether the issue of profitability variables and the bank size can affect corporate zakat expenditure by BUS in Indonesia.

\section{LITERATURE REVIEW}

\section{Corporate Zakat}

Corporate zakat is analogous to zakat imposed on the trade sector. According to BAZNAS (2018), the emergence of term corporate zakat is motivated by ownership of a company which is mostly not owned by individuals but is owned jointly in the form of institutions and organizations managed in the way of certain legal entities. According to Law No. 21 of 2008 on Sharia Banking, notably of its fundamental, it is obvious that BUS is one of the subjects of muzaki which are obliged to expend zakat which has been regulated by the existing laws. In the Al-Qur'an, the command of zakat is in Q.S At-Taubah [9]:103 as follows:
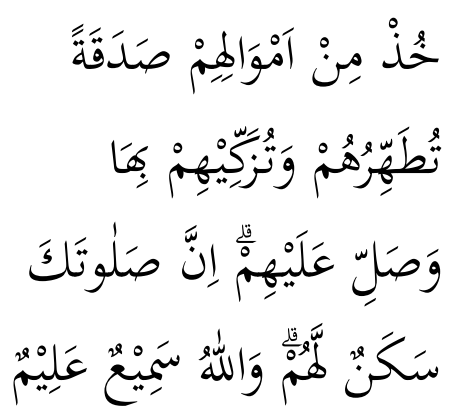

Meaning: Take alms from their wealth, to cleanse and purify them, and pray for them. Verily that prayers (grows) peace of mind for them. And Allah hearer, the knower.

The juridical rules of zakat are regulated in Article 11 Section (2) part b, where trade assets and companies are one of the objects of zakat. Further, the 
Law No. 23 of 2011 in Article 4 Section (2) part $\mathrm{c}$ and Article 4 Section (3), governs that commerce is one of the sectors which obligated to pay zakat maal and business entities mentioned explicitly as types of muzaki other than muzaki with kind of individual.

\section{Terms of Nisab and Rates of Corporate Zakat}

According to BAZNAS (2018), because corporate zakat is analogous of trade zakat, the rules which applied trade zakat, also applied to corporate zakat. BAZNAS (2018) added that nisab, rates, and time of corporate zakat payment are the same as nisab, rate, and time of trade zakat payment which is 85 grams (if using of the gold standard) and the business has lasted for one year.

Meanwhile, the requirements of corporate zakat, according to Arifin (2011) are divided into five conditions as follows:

1. Muslims own company ownership;

2. Halal business fields;

3. Company assets can be assessed;

4. Company assets can develop; and

5. A minimum of corporate wealth is equivalent to 85 grams of gold.

In calculating corporate zakat, Accounting and Auditing Organization for Islamic Financial Institutions (AAOIFI) (2008) has issued Financial Accounting Standards (FAS) Number 9 as a reference for the subject matters. It is calculated using two methods, which are the Net Asset Method and Net Invested Fund/Net Equity Method. It is 2.5 percent due based on the lunar calendar, and 2.5775 percent of zakat rate if using the solar calendar.

The formula for calculating corporate zakat using Net Asset Method and Net Invested Fund/Net Equity
Method are formulas follows AAOIFI (2008):

1. Net Asset Method

Zakat base $=$ Assets subject to zakat - (liabilities that are due to be paid during the year ended on the date of statement of financial position + equity of unrestricted investment accounts + minority interest + equity owned by government + equity owned by endowment funds + equity owned by charities + equity belonging to not-for-profit organizations excluding those that are owned by individuals)..............(1)

2. Net Invested Fund/Net Equity

Zakat base $=$ Paid-up capital + reserves + provisions not deducted from assets + retained earnings + net income + liabilities that are not due to be paid during the year ended on the date of the statement of financial position - (net fixed assets + investments not acquired for trading, e.g., real estate for rent + accumulated

losses)

Relationship of Profitability Variables and Bank Size toward Corporate Zakat Expenditure by BUS

Several types of research have been conducted, for instance; Maali, Casson, \& Napier (2006), conducted social reporting disclosure by Islamic Banks. Of the findings concluded that Islamic banks in sixteen countries had not carried out social banking functions properly, as one of them not paying corporate zakat. Md Arif, Alwi \& Tahir (2011) studied factors which influence Malaysian firms to pay zakat. The finding indicated that collection of corporate zakat funds in Malaysia tended 
to be low. Firmansyah \& Rusydiana (2019) investigated the effects of profitability on zakat expenditures by Indonesian BUS. They concluded that bank size (total assets) moderated the effect of profitability (ROA) on corporate zakat expenditure by BUS.

Samad et al. (2015) investigated the correlation between zakat payment and firm's performance among Malaysian Islamic Banks. They concluded that total variable assets provided a positive effect on corporate zakat expenditure. Meanwhile, the profitability variables, which were ROA, ROE, and NPF, had a negative impact on corporate zakat expenditure by Islamic banks in Malaysia. Abbas, Sulaiman, \& Bakar (2018) reviewed Zakat Payments by Malaysian Islamic Banks and found that Islamic banking in Malaysia tended to be low in the subject matters as per calculated using the growth model and working capital model.

Utami (2018) researched the Influence of financing to deposit ratio (FDR), non-performing financing (NPF) and BOPO on zakat compliance in Indonesian Islamic Banks over 20112015. She found that only FDR which had a significant effect on compliance of zakat payments by BUS in Indonesia. Utari \& Ninglasari (2019) analyzed the factors influencing corporate zakat expenditure in Indonesian context with the period of 2015-2017. They found that ROA was insignificantly affected the corporate zakat expenditure by BUS. However, conversely did ROE and total assets.

Reviewing the above, we recognized that most of the studies had employed regression analysis model. In this work, the Panel Vector Error Correction Model (PVECM) data analysis technique is engaged to produce two beneficial analyses, which are the Impulse Response Function (IRF) and Variance Decomposition (VDC). IRF is useful to analyze the effect of each shock independent variable (ROA, ROE, BOPO, and total assets) toward its dependent variable response (corporate zakat expenditure by BUS). While, VDC is beneficial to analyze the composition of formation of the dependent variable (corporate zakat expenditure by BUS) from its independent variables (ROA, ROE, BOPO, and total asset).

\section{RESEARCH METHODOLOGY}

\section{Type and Data Source}

We considered secondary data with panel data of Islamic banks' annual reports from 2010 to 2017. The data was divided into two variables, which were dependent and independent variables. Our dependent variable was corporate zakat expenditure, while the independent variables were profitability variables of Return on Assets (ROA), Return on Equity (ROE) and Operational Costs to Operating Income (BOPO) and bank size represented by total assets.

\section{Operational Definition of Research Variables}

In order to find out the effects, further testing is carried out using Panel Vector Error Correction Model (PVECM) which the dependent variable and independent variables used were as follows: 
Table 2. Operational Definition of Research Variables

\begin{tabular}{l|c|c|c|l}
\hline Variable Name & Category & Symbol & Unit & \multicolumn{1}{c}{ Definition } \\
\hline $\begin{array}{l}\text { Corporate Zakat } \\
\text { Expenditure }\end{array}$ & Dependent & Zakat_Paid & $\begin{array}{l}\text { Billion } \\
\text { Rupiah }\end{array}$ & $\begin{array}{l}2.5 \% \text { x (current assets - } \\
\text { short-term liabilities) }\end{array}$ \\
\hline Return on Asset & Independent & ROA & Percent & $\begin{array}{l}\text { Net profit before tax/total } \\
\text { assets }\end{array}$ \\
\hline $\begin{array}{l}\text { Return on Equity } \\
\text { Independent }\end{array}$ & ROE & Percent & $\begin{array}{l}\text { Net profit after tax/total } \\
\text { capital }\end{array}$ \\
\hline $\begin{array}{l}\text { Operational Costs } \\
\text { to Operating } \\
\text { Income }\end{array}$ & Independent & BOPO & Percent & $\begin{array}{l}\text { Operational costs/Operating } \\
\text { income }\end{array}$ \\
\hline \begin{tabular}{l} 
Total Assets \\
\hline
\end{tabular} & Independent & T_Assets & $\begin{array}{l}\text { Billion } \\
\text { Rupiah }\end{array}$ & $\begin{array}{l}\text { The logarithm of all assets } \\
\text { owned by BUS }\end{array}$ \\
\hline
\end{tabular}

Source: https://baznas.go.id/zakatperusahaan and SEOJK No. 18/SEOJK.03/2015 on Transparency and Publication of Islamic Commercial Bank and Islamic Business Unit Reports

\section{Population and Sample}

The population of this research is the Indonesian 13 BUS. The sample was selected using purposive sampling. According to Umar (2002), purposive sampling is a technique of determining samples using specific considerations. In this, we have taken into account the followings:

1. Islamic Commercial Bank has been registered in the Financial Services Authority (FSA) Republic of Indonesia.

2. Islamic Commercial Bank has published a financial report including corporate zakat expenditure during the period 2010 - 2017.

From the sample above, then we sampled five Islamic Commercial Banks, which are Mandiri Sharia Bank, BNI Sharia, Muamalat Bank, BRI Sharia, and Mega Sharia Bank.

Data Analysis Technique
The data analysis technique used in this research is the Panel Vector Error Correction Model (PVECM). It is a Vector Autoregression (VAR) method that is estimated by the existence of cointegration or long-run relationships between all variables used. Generally, PVECM estimate is carried out using time series. However, according to Groen \& Kleibergen (1999), panel data can be done using a likelihood-based framework on cointegration testing. PVECM provides two analysis, which are the Impulse Response Function (IRF) and Variance Decomposition (VDC). IRF is used to analyze the shock of each independent variable toward the response of its dependent variable. While VDC is used to analyze the composition of formation of the dependent variable by their independent variables.

According to Anderson, Qian \& Rasche (2006), PVECM equation can be obtained by modifying equations of each in the panel data used. PVECM equation used in this research is as follows: 
$\Delta y_{t}=\delta d_{t}+a \beta^{\prime} y_{t-1}+\Gamma X_{t}+\varepsilon_{t}$ for $\mathrm{t}=1,2$,

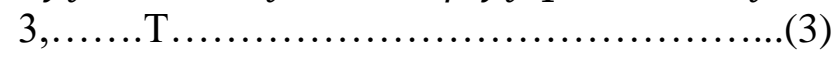

Where:

$\Delta y_{t}=\left[\begin{array}{c}\Delta y_{1 t} \\ \Delta y_{2 t} \\ : \\ \Delta_{N t}\end{array}\right] ; \quad \delta=\left[\begin{array}{c}\delta_{1} \\ \delta_{2} \\ : \\ \delta_{N}\end{array}\right] ; \alpha=\left[\begin{array}{llll}a_{11} & & & \\ & a_{22} & & \\ & & \ddots & \\ & & & a_{N N}\end{array}\right] ; \beta=\left[\begin{array}{llll}\beta_{11} & & & \\ & \beta_{22} & & \\ & & \ddots & \\ & & \beta_{N N}\end{array}\right]$

$y_{t-1}=\left[\begin{array}{c}y_{1 t-1} \\ y_{2 t-2} \\ \vdots \\ \cdot \\ y_{N t-1}\end{array}\right] ; \quad \Gamma=\left[\begin{array}{cccc}\Gamma_{11} & \Gamma_{12} & \ldots & \Gamma_{1 N} \\ \Gamma_{21} & \Gamma_{22} & \ldots & \Gamma_{2 N} \\ \vdots & \vdots & \ldots & \vdots \\ \Gamma_{N 1} & \Gamma_{N 2} & \ldots & \Gamma_{N N}\end{array}\right] ; \quad X_{t}=\left[\begin{array}{c}X_{i t} \\ X_{2 t} \\ : \\ \cdot \\ X_{N t}\end{array}\right] ; \quad \varepsilon_{t}=\left[\begin{array}{c}\varepsilon_{1 t} \\ \varepsilon_{2 t} \\ : \\ \cdot \\ \varepsilon_{N t}\end{array}\right] ; \quad y_{i t}=$ $\left[\begin{array}{c}\log (\text { ZakatPaid })_{i t} \\ \log (\text { ROA })_{i t} \\ \log (\text { ROE })_{i t} \\ \log (\text { BOPO })_{i t} \\ \log (\text { tassets })_{i t}\end{array}\right] \ldots \ldots \ldots .(5)$

Note:

$\Delta \mathrm{y}_{\mathrm{t}} \quad=$ Difference matrix $\mathrm{p}$ of variables examined

$\mathrm{y}_{\mathrm{t}-1}=\mathrm{Lag} 1$ of matrix variable examined

$\delta=$ Parameter matrix of model determinant component

$\mathrm{d}_{\mathrm{t}} \quad=$ Vector determinant component to $\mathrm{t}$

$\alpha \beta^{\prime} \quad=$ Matrix of long-run equation

$\alpha=$ Matrix of diagonal adjustment

$\beta=$ Matrix of diagonal cointegration

$\Gamma \quad=$ Matrix of dynamic short-run equation

$\mathrm{X}_{\mathrm{t}} \quad=$ Difference matrix is examined on lag operator of $\mathrm{k}$

$\varepsilon_{\mathrm{t}} \quad=$ Matrix of error term

Zakat_Paid $\mathrm{it}_{\mathrm{it}}=$ Corporate zakat expenditure by BUS to $\mathrm{i}$ in year $\mathrm{t}(\mathrm{i}=1,2 \ldots .5$ and $\mathrm{t}=$ $1,2,3 \ldots 8)$

$\mathrm{ROA}_{i t}=$ ROA value of BUS to $\mathrm{i}$ in year of $\mathrm{t}(\mathrm{i}=1,2 \ldots .5$ and $\mathrm{t}=1,2,3 \ldots .8)$

$\mathrm{ROE}_{\mathrm{it}}=$ ROE value of BUS to $\mathrm{i}$ in year of $\mathrm{t}(\mathrm{i}=1,2 \ldots .5$ and $\mathrm{t}=1,2,3 \ldots 8)$

$\mathrm{BOPO}_{\mathrm{it}}=\mathrm{BOPO}$ value of BUS to $\mathrm{i}$ in year of $\mathrm{t}(\mathrm{i}=1,2 \ldots .5$ and $\mathrm{t}=1,2,3 \ldots 8)$

$\mathrm{T} \_$Assets $\mathrm{it}_{\mathrm{t}}=$ Total assets of BUS to $\mathrm{i}$ in year of $\mathrm{t}(\mathrm{i}=1,2 \ldots .5$ and $\mathrm{t}=1,2,3 \ldots .8)$

Prior to the analysis, to ensure the validity of the model, we tested stationary data using Levin, Lin \& Chu t, ADF - Fisher Chi-square and PP - Fisher Chi-square, determining of optimal lag length using Schwarz Information Criterion (SIC) and conducted cointegration test using Kao Residual Cointegration Test.

\section{RESULTS AND DISCUSSIONS}

\section{Data Stationary Test}

The output of data stationarity test using panel unit root test showed that most of the research variables used namely corporate zakat expenditure, ROA, ROE, BOPO, and total assets did not include stationer at the level of significance $\alpha=$ 
5 percent. However, after conducting data stationary test at first difference, all research variables were stationer showing by probability values of Levin, Lin \& Chu t, ADF - Fisher Chi-square and PP - Fisher Chi-square which were smaller than $\alpha=5$ percent meaning that one of PVECM requirements has been fulfilled and further testing can be carried out.

Table 3. Output of Stationary Test Each Variable Used

\begin{tabular}{|l|c|c|c|c|c|c|}
\hline \multirow{2}{*}{ Variable } & \multicolumn{3}{|c}{ Level } & \multicolumn{3}{c|}{ First Difference } \\
\cline { 2 - 7 } & $L L C$ & $A D F$ & $P P$ & $L L C$ & $A D F$ & $P P$ \\
\hline Zakat_Paid & 0.0011 & 0.0132 & 0.0559 & 0.0000 & 0.0000 & 0.0000 \\
\hline ROA & 0.0335 & 0.0217 & 0.0156 & 0.0000 & 0.0000 & 0.0000 \\
\hline ROE & 0.2785 & 0.1140 & 0.0910 & 0.0000 & 0.0000 & 0.0000 \\
\hline BOPO & 0.6163 & 0.9673 & 0.9585 & 0.0000 & 0.0000 & 0.0000 \\
\hline T_Assets & 1.0000 & 0.9996 & 1.0000 & 0.0000 & 0.0000 & 0.0000 \\
\hline
\end{tabular}

Source: Computed by Author (2019)

\section{Length Lag Optimum Criteria}

Length of lag included in this research was between lag 1 to lag 3 with consideration of the best model produced from PVECM estimation. Based on the results of the optimum lag test in table 4, between lags 1 - 3, it was known that optimum lag was found in lag 1 which is shown by the minimum value of Schwarz Information Criterion (SIC). Then, lag 1 was used in PVECM estimation.

Table 4. The output of Length Lag Optimum Criteria

\begin{tabular}{|c|c|c|}
\hline Lag & AIC Value & SIC Value \\
\hline $\mathbf{0}$ & 4.261788 & 4.505563 \\
\hline $\mathbf{1}$ & -1.157617 & $\mathbf{0 . 3 0 5 0 3 4} *$ \\
\hline $\mathbf{2}$ & -1.869872 & 0.811655 \\
\hline $\mathbf{3}$ & $\mathbf{- 2 . 3 3 5 8 6 8}$ & 1.564534 \\
\hline
\end{tabular}

Source: Computed by Author (2019)

\section{Cointegration Test}

The output of cointegration test using Kao Residual Cointegration Test showed that all variables used namely corporate zakat expenditure, ROA, ROE, BOPO, and total assets had cointegration relationship which was shown by $\mathrm{p}-$ value of 0.001 ( $\mathrm{p}$-value < 0.05 ), meaning that all variables had significant cointegration relationship.

\section{PVECM Estimation Output}

After testing all variables to ensure that estimation model was valid, then the output of PVECM estimation of determinants of corporate zakat expenditure by BUS in Indonesia analyzed from profitability variables and bank size, the result is as in table 5 
Table 5. The output of PVECM Estimation

\begin{tabular}{|c|c|c|}
\hline Variable & Short-Run Coefficient & t-Statistic \\
\hline D(LOGZAKAT_PAID(-1)) & -0.026772 & {$[-0.15064]$} \\
\hline D(LOGROA $(-1))$ & -2.962571 & {$[-1.54634]$} \\
\hline D(LOGROE(-1)) & 1.777013 & [1.10349] \\
\hline D(LOGBOPO(-1)) & 3.342126 & {$[0.43293]$} \\
\hline D(LOGT_ASSETS(-1)) & -3.294901 & {$[-1.32828]$} \\
\hline CointEq1 & -0.543808 & {$[-2.94118]$} \\
\hline $\mathrm{C}$ & 0.706733 & {$[1.26987]$} \\
\hline Variable & Long-Run Coefficient & t-Statistic \\
\hline D(LOGROA(-1)) & -4.687842 & {$[-5.77265]$} \\
\hline D(LOGROE(-1)) & 2.832541 & {$[4.46477]$} \\
\hline D(LOGBOPO(-1)) & 15.67965 & [2.66660] \\
\hline D(LOGT_ASSETS(-1)) & -2.234579 & {$[-6.01918]$} \\
\hline C & & \\
\hline
\end{tabular}

Source: Computed by Author (2019)

From PVECM estimation table above, it can be explained that in the short-run all independent variables used namely ROA, ROE, BOPO, and total assets did not have a significant effect on corporate zakat expenditure by BUS in Indonesia. In detail, the explanation of the impact of each independent variable on corporate zakat expenditure by BUS in short-run was as follows:

- ROA variable showed a negative and not significant effect on corporate zakat expenditure by BUS.

- ROE variable showed a positive but not significant effect on corporate zakat expenditure by BUS.

- BOPO variable showed a positive but not significant effect on corporate zakat expenditure by BUS.

- Total assets variable showed a negative and not significant effect on corporate zakat expenditure by BUS.
The output of PVECM estimation in short-run above was per BAZNAS (2016), which stated that the awareness in terms of corporate zakat payments by business entities has not been as high as the awareness of zakat payments by individuals. BUS orientation still tended to be profitoriented, and does not give more attention to the social intermediation function. Furthermore, in the long run, it can be explained that all independent variables used had a significant effect on corporate zakat expenditure by BUS in Indonesia. These effects were explained in detail as follows:

- ROA variable had a negative and significant effect on corporate zakat expenditure by BUS with coefficient value as big as -4.68 which means that if there is an increase in ROA ratio as big as 1 percent it will provide a probability of decreasing corporate zakat expenditure by BUS as big as -4.68 percent. 
- ROE variable showed the opposite of ROA which gave a positive and significant effect on corporate zakat expenditure by BUS with coefficient value as big as 2.83 which means that if there is an increase in ROE ratio as big as 1 percent it will be followed by an increase in the potential of corporate zakat expenditure by BUS as big as 2.83 percent.

- BOPO variable also showed the same as ROE which gave a positive and significant effect on corporate zakat expenditure by BUS, with coefficient of 15.67 , which means that if there is an increase in BOPO ratio of 1 percent, it will be followed by an increase in the potential of corporate zakat expenditure by BUS of 15.67 percent.

- Total assets variable gave a negative and significant effect on corporate zakat expenditure by BUS with a coefficient value of 2.23. This means that if there is a growth of BUS assets at 1 billion Rupiah, then it is not necessarily followed by an increase in the potential of corporate zakat expenditure by BUS. However, on the contrary, it reduces corporate zakat expenditure by BUS of -2.23 percent.

The long-run PVECM estimation results above were per the previous research conducted by Samad et al. (2015), Utami (2018) and Utari \& Ninglasari (2019), which stated that profitability variables and total assets of Islamic banks did not always give the effects on corporate zakat expenditure by Islamic banks. In other words, the Islamic bank has not focused on social functions and still tend to be profitoriented as evidenced by the absence of a correlation between profitability variables and total assets on corporate zakat expenditure.

\section{Impulse Response Function (IRF)}

The first PVECM estimation output that can be used to analyze the response of corporate zakat expenditure by BUS toward the shock of ROA, ROE, BOPO, and total assets is Impulse Response Function (IRF). The IRF results in this research are shown in the figure as follow:

Figure 1. Output of Impulse Response Function (IRF) Analysis
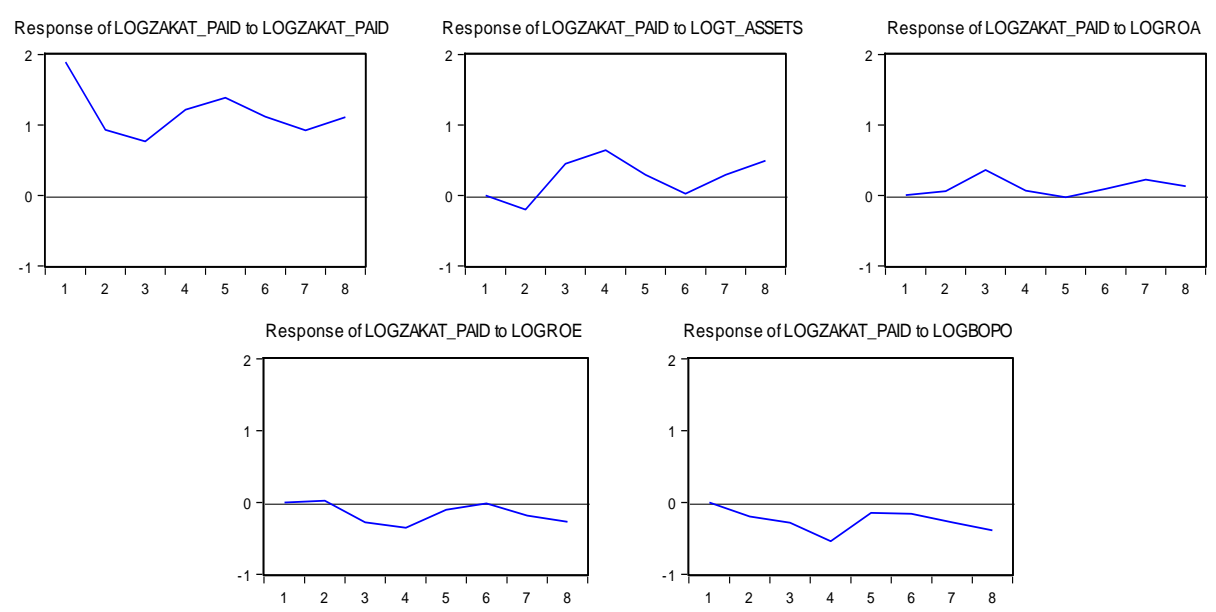

Source: Computed by Author (2019) 
Through the picture above, it can be explained that the shock of corporate zakat expenditure itself contributes to the decreasing in corporate zakat expenditure by BUS of 0.92 percent, which occurred from the second period and tended to fluctuate until the eighth period used in this research. In addition, the response of corporate zakat expenditure to the shock of ROA showed a positive response and tended to increase until the fourth period. However, in the fifth period of ROA, the shock was responded negatively by corporate zakat expenditure, which caused a decrease in corporate zakat expenditure by BUS of -0.029 percent.

Furthermore, the shock of ROE was responded positively by corporate zakat expenditure in the second period, which increased corporate zakat expenditure by BUS with 0.02 percent. However, in the third period to the eighth period, showed that the shock of ROE was responded negatively by corporate zakat expenditure, which caused a decrease in corporate zakat expenditure by BUS.
The same thing occurred in BOPO shock towards the response of corporate zakat expenditure by BUS. The response of corporate zakat expenditure toward BOPO shock showed a negative response from the second period to the eighth period known by the blue line at the bottom of the balance line which caused a decreasing in corporate zakat expenditure by BUS. A different response was shown by the reaction of corporate zakat expenditure toward the shock of total assets, which showed fluctuations up to the eighth period.

\section{Variance Decomposition (VDC)}

The second output generated from PVECM estimation is Variance Decomposition (VDC). The output can be used to analyze the contribution of each independent variable to the formation of its dependent variable. The VDC analysis results are shown in the table as follows:

Table 6. Output of Variance Decomposition (VDC) Analysis

\begin{tabular}{ccccccc} 
Period & S.E. & Log Zakat Paid & LogT_Assets & LogROA & LogROE & LogBOPO \\
\hline $\mathbf{1}$ & 1.889423 & 100.0000 & 0.000000 & 0.000000 & 0.000000 & 0.000000 \\
$\mathbf{2}$ & 2.123492 & 98.17024 & 0.895742 & 0.077995 & 0.010129 & 0.845891 \\
$\mathbf{3}$ & 2.362640 & 89.85381 & 4.275307 & 2.391920 & 1.371039 & 2.107924 \\
$\mathbf{4}$ & 2.808947 & 82.27611 & 8.254545 & 1.746034 & 2.568047 & 5.155259 \\
$\mathbf{5}$ & 3.150488 & 84.72231 & 7.414896 & 1.396917 & 2.148161 & 4.317719 \\
$\mathbf{6}$ & 3.346944 & 86.14835 & 6.574436 & 1.313398 & 1.905684 & 4.058131 \\
$\mathbf{7}$ & 3.506322 & 85.41899 & 6.668614 & 1.592034 & 2.007357 & 4.313001 \\
$\mathbf{8}$ & 3.742293 & 83.75705 & 7.562205 & 1.517561 & 2.285481 & 4.877699
\end{tabular}

Source: Computed by Author (2019)

Through the picture above, it can be explained that corporate zakat expenditure by BUS in the first period was affected by corporate zakat expenditure by BUS itself, which was equal to 100 percent. Other variables were known not to contribute to the formation of corporate zakat expenditure by BUS. In the second period and onward, all independent variables had 
shown their contribution to the formation of corporate zakat expenditure by BUS with the highest contribution which was affected by total assets with 89.5 percent, BOPO with 84.5 percent, ROA with 7.79 percent, and ROE with 1.01 percent. The contribution of all independent variables to the formation of corporate zakat expenditures by BUS showed a trend that declined to the eighth period used in this research.

\section{CONCLUSION}

The PVECM estimation results showed that in the short-run, all independent variables used did not have a significant effect on the dependent variable (corporate zakat expenditure by BUS). This situation showed that the awareness of BUS to pay corporate zakat is relatively low. Furthermore, in the longrun, all independent variables had a significant effect on corporate zakat expenditure by BUS. Other results based on IRF showed that the shock of all independent variables tended to be responded by the dependent variable (corporate zakat expenditure), with fluctuating trends and even negative. In addition, based on VDC showed that the contribution of each independent variable to the formation of the dependent variable showed a pattern that declined until the end of the research period. PVECM used in this research which produced two beneficial analysis, namely IRF and VDC being a novelty from this research because most of the previous research only used regression as a data analysis technique.

However, this research has limitations, which is the sample used only consisted of five BUS operating in Indonesia during the period $2010-2017$. Therefore, future researchers can employ more sample and data.

\section{REFERENCES}

Abbas, S. Z. M., Sulaiman, S., \& Bakar, N. A. (2018). A Review on Zakat Payments by Islamic Banks in Malaysia. International Journal of Zakat, 3(4), 71-82. Retrieved from https://ijazbaznas.com/index.php/j ournal/article/view/107

Accounting and Auditing Organization for Islamic Financial Institutions. (2008). Financial Accounting Standards (FAS) $9-$ Zakah. Manama, Bahrain: Authors.

Anderson, R. G., Qian, H., \& Rasche, R. (2006). Analysis of Panel Vector Error Correction Models Using Maximum Likelihood, the Bootstrap, and CanonicalCorrelation Estimators. Ssrn. https://doi.org/10.2139/ssrn.92744 3

Arifin, G. (2011). Zakat, Infak, Sedekah. Retrieved from https://books.google.co.id/books?i $\mathrm{d}=$ MQRGDwAAQBAJ

Badan Amil Zakat Nasional. (2016). Outlook Zakat Indonesia 2017. Jakarta: Pusat Kajian Strategis (PUSKAS) BAZNAS.

Badan Amil Zakat Nasional. (2018). Zakat Perusahaan. Retrieved from http://baznas.go.id/zakatperusahaa $\mathrm{n}$

Badan Amil Zakat Nasional. (2018). Statistik Zakat Nasional 2017. Jakarta: BAZNAS.

Firdaus, M. et al. (2012). Economic estimation and determinations of Zakat potential in Indonesia. Islamic Research and Training Institute, WP 1433-07(August), 174. Retrieved from http://www.isdb.org

Firmansyah, I., \& Rusydiana, A. S. (2013). Pengaruh Profitabilitas Terhadap Pengeluaran Zakat Dengan Ukuran Perusahaan 
Sebagai Variabel Moderasi Pada Bank Umum Syariah Di Indonesia. Jurnal Pendidikan Akuntansi \& Keuangan, $5(1)$. https://doi.org/10.17509/jpak.v5i1 .15379

FSA. (2018). Laporan Perkembangan Keuangan Syariah Indonesia 2017. Financial Services Authority, p. 103. Retrieved from https://www.ojk.go.id/id/beritadan-

kegiatan/publikasi/Pages/Laporan -Perkembangan-KeuanganSyariah-2017.aspx

Groen, J. J. J., \& Kleibergen, F. (1999). Likelihood-Based Cointegration Analysis in Panels of Vector Error Correction Models *. 1-44.

Instruksi Presiden Republik Indonesia Nomor 3 Tahun 2014 tentang Optimalisasi Pengumpulan Zakat di Kementerian/Lembaga, Sekretariat Jenderal Lembaga Negara, Sekretariat Jenderal Komisi Negara, Pemerintah Daerah, Badan Usaha Milik Negara, dan Badan Usaha Milik Daerah Melalui Badan Amil Zakat Nasional.

Maali, B., Casson, P., \& Napier, C. (2006). Social reporting by islamic banks | ReadCube Articles. Abacus, 42(2). https://doi.org/10.1111/j.14684497.2006.00200.x

Md Arif, H., Alwi, K., \& Tahir, A. M. (2011). Factors influence company towards zakat payment: An explanatory studies. 2nd International Conference on Business and Economic Research, 2515-2522.

Samad, K. A., Said, R., Kamarulzaman, M. H., \& Mahshar, M. (2015). Exploring the Zakat Payment and
Firm's Performance of Islamic Banks in Malaysia. The 6th International Conference on Governance, Fraud, Ethics and Social Responsibility 2015 (IConGFESR 2015) Exploring, 2015(June), 1-6.

Surat Edaran Otoritas Jasa Keuangan Nomor 18/SEOJK.03/2015 tentang Transparansi dan Publikasi Laporan Bank Umum Syariah dan Unit Usaha Syariah.

Undang-Undang Republik Indonesia Nomor 38 Tahun 1999 tentang Pengelolaan Zakat.

Undang-Undang Republik Indonesia Nomor 21 Tahun 2008 tentang Perbankan Syariah.

Undang-Undang Republik Indonesia Nomor 23 Tahun 2011 tentang Pengelolaan Zakat.

Umar, H. (2002). Metode riset bisnis: panduan mahasiswa untuk melaksanakan riset dilengkapi contoh proposal dan hasil riset bidang manajemen dan akuntansi. Retrieved from https://books.google.co.id/books?i $\mathrm{d}=\mathrm{ihn} 8 \mathrm{~T} 5 \mathrm{~S} 8 \mathrm{HaQC}$

Utami, T. (2018). The Influence of Financing to Deposit Ratio (FDR), Non-Performing Financing (NPF), dan BOPO on Zakat Compliance in Islamic Banks in Indonesia Period 2011-2015. Economics and Accounting Journal, 1(1), January 2018, pp. 53-63.

Utari, R., Monoarfa, H., \& Yayu Ninglasari, S. (2019). Factors Influencing Corporate Zakat Expenditure (Case Study of Islamic Banks in Indonesia Period 2015-2017). KnE Social Sciences, $3(13)$, 413. https://doi.org/10.18502/kss.v3i13 .4220 